\title{
COMPETITIVENESS AND INNOVATION CHALLENGE IN CROATIA *
}

\author{
Lena Duspara ${ }^{1}$, Sanja Knežević ${ }^{2}$ \& Mladen Turuk ${ }^{3}$
}

UDC / UDK: 339.13:001.895](497.5)

JEL classification / JEL klasifikacija: L31, O31

DOI: https://doi.org/10.22598/pi-be/2017.11.2.41

Review / Pregledni rad

Received / Primljeno: September 28, 2017 / 28. rujna 2017.

Accepted for publishing / Prihvaćeno za tisak: November 27, 2017 / 27. studenoga 2017.

\section{Summary}

Competitiveness is a concept we all want to achieve, but it is very difficult to define, and even harder to implement. An important feature of competitiveness is its dynamic nature, because sources of competitiveness are not permanent. Competitiveness is a matter of growing interest for every country, which is concerned about the success of its industries and nations. For understanding the current economic situation, it is necessary to know the historical background because it affects the current situation and competitiveness of the economy. Competitiveness is the most commonly defined economic concept in the last 30 years. It is in the interest of every country to be competitive and that the industry is export-oriented. To be competitive in the demanding EU market and on the global market is the task of both enterprises and the economy of the Republic Croatia.

The purpose of this paper is to link international competitiveness with the lack of innovative activity in Croatia. Innovation capacity and sophistication of production technology are one of the main problems of business competitiveness in Croatia. This paper researches the indicators of competitiveness and innovation index parameters that determine the position of the Republic of Croatia on the regional and the global level. The aim is to show the influence of the national competitiveness and innovation standard on entrepreneurship in Croatia.

Key words: competitiveness, innovation, problems, Croatia.

\footnotetext{
The paper was presented at the 2nd International Conference „Business \& Entrepreneurial Economics -BEE2017” which was held in Brijuni from 24 to 26 May 2017 (www.bee-conference.com)

1 Lena Duspara, Ph.D, senior lecturer, College of Slavonski Brod, Slavonski Brod, Croatia, E-mail: lena. duspara@vusb.hr

2 Sanja Knežević, Ph.D, senior lecturer, College of Slavonski Brod, Slavonski Brod, Croatia, E-mail: sanja. knezevic@vusb.hr

3 Mladen Turuk, Ph.D., assistant, Faculty of Economics and Business, University of Zagreb, Croatia, E-mail:mturuk@efzg.hr
} 


\section{INTRODUCTION}

In the modern economy, innovation and innovativeness represent the main factors of development and competitiveness of enterprises. Their significance is even stronger thanks to modern processes, especially the increased global competitiveness. Innovation is crucial for long-term growth and survival of almost all enterprises. Its significance lies in the fact that it creates growth, increases productivity and wealth of the economy, contributes to a higher standard, etc. It implies that enterprises that do not innovate, do not usually survive in the market. The significance of innovations for the enterprise is precisely surviving. Maintaining competitive advantages implies that enterprises have to be innovative and constantly deal with various strategies in order to be more successful.

\section{INNOVATION AS INITIATOR OF ECONOMY}

Innovation is a very complex term and it can be defined through its different aspects. A number of definitions exist today. The term "innovation" comes from the Latin word innovare, which means to do something new. According to the European Commission, innovation "is the improvement and increase in the volume of products, services, and related markets, the establishment of new methods of production, supply and distribution, the introduction of changes in management, organization and working conditions of employees." (Green Paper on Innovation, 1995). Innovations are an indication of how much a society is advanced. Innovation stimulates a range of segments, human resources, finance, production, marketing, research and development, etc. Innovativeness of enterprises is measured through efforts to find new opportunities and innovative solutions. It includes creativity and experimentation that might lead to new products or improved technological processes.

OECD (2005:47-51) defines four different types of innovation: (1) Product innovation, (2) Process innovation, (3) Marketing innovation and (4) Organisational innovation. "A product innovation is the introduction of a good or service that is new or significantly improved with respect to its characteristics or intended uses. This includes significant improvements in technical specifications, components and materials, incorporated software, user friendliness or other functional characteristics." (OECD, 2005:48). "A process innovation is the implementation of a new or significantly improved production or delivery method. This includes significant changes in techniques, equipment and/or software." (OECD, 2005:49). "A marketing innovation is the implementation of a new marketing method involving significant changes in product design or packaging, product placement, product promotion or pricing." (OECD, 2005:49). "An organisational innovation is the implementation of a new organisational method in the firm's business practices, workplace organisation or external relations." (OECD, 2005:51). The environment in which the enterprise is located, as well as its own innovativeness affects the level of innovation. Managing innovation can be very challenging.

In recent times, Croatia as a small country of the European Union has been faced with great challenges. Currently, only a small number of enterprises in Croatia base 
their business on innovation. Innovations are closely related to the level of investment. Today, Croatia is characterized as a country with a low level of investment. In order to increase the level of competitiveness it is essential that enterprises introduce new production technology with which they will be able to compete in the European and global markets. Because of the poor economic situation and the impact of the economic crisis, many enterprises are less willing to invest. Respectively, many are discouraged because of an uncertain future. Historical heritage and business habits have a major impact on the current situation in the economy. Table 1 below shows the share of gross investment in fixed assets in the period from 1960 to 1987 in the Republic of Croatia in comparison to other countries.

Table 1: The share of gross investments in fixed assets in GDP in \%

\begin{tabular}{|l|c|c|c|c|c|}
\hline & $\mathbf{1 9 6 0 . - 6 7 .}$ & $\mathbf{1 9 6 8 . - 7 3 .}$ & $\mathbf{1 9 7 4 . - 7 9 .}$ & $\mathbf{1 9 8 0 . - 8 7 .}$ & $\mathbf{1 9 6 0 . - 8 7 . ~}$ \\
\hline Yugoslavia & 32.1 & 30.6 & 33.1 & 24.0 & 28.7 \\
\hline Croatia & 29.4 & 28.3 & 30.9 & 22.8 & 26.9 \\
\hline EEC & 22.7 & 23.5 & 22.1 & 19.9 & 21.9 \\
\hline OECD & 21.0 & 22.3 & 22.3 & 20.5 & 21.5 \\
\hline Japan & 31.0 & 31.6 & 31.6 & 29.0 & 31.4 \\
\hline
\end{tabular}

Source: Sirotković, 1996:14

According to the data in Table 1, Croatia had a lower share of investment in relation to Yugoslavia, but both had a higher proportion of investment than EEC (European Economic Community) and OECD (Organisation for Economic Co-operation and Development) countries, except Japan. The largest increase in gross investment was in the period from 1974 to 1979. Changes in investments reflected on the growth of the overall economy shown in next table. The next parameter is technological progress, which is the result of innovation and investment levels. The growth of technological progress is essential for the country's economy. The most developed world economies such as Japan are not leaders because of numerous and significant innovations, but because of the constant daily technological progress. In addition, the Croatian economy might be at least a regional leader based on continuous technological progress. Table 2 shows the growth rate of technological progress in the Republic of Croatia and selected countries.

Table 2: Technological progress - growth rates

\begin{tabular}{|l|c|c|c|}
\hline & unitl 1973. & 1973.-79. & $\mathbf{1 9 7 9 . - 8 7 . ~}$ \\
\hline Croatia & 2.7 & 1.1 & -1.7 \\
\hline Yugoslavia & 2.4 & 1.5 & -1.6 \\
\hline EEC & 3.3 & 1.5 & 0.9 \\
\hline OECD & 2.8 & 0.8 & 0.7 \\
\hline Japan & 6.3 & 1.8 & 1.9 \\
\hline
\end{tabular}

Source: Sirotković, 1996:15 
Croatia and Yugoslavia had minor differences in technological progress and labour productivity in relation to other countries. This is the result of high rates of investment that enabled faster growth in employment. One characteristic of the system was expensive investment and cheap labour. This resulted in low efficiency of investment, low level of productivity, and poor employment policy. The main activities of the economy in Croatia were the manufacturing industry and the service sector.

Development of innovative activity is difficult because of the effect of many factors. One of the biggest obstacles to the realization of market innovations is primarily the lack of financial resources. Extremely little money is invested in research and development. According to Eurostat, the Republic of Croatia invests less than 1\% of GDP into research and development, which is a devastating fact and reflects the current economic situation in Croatia. While in most EU countries investments grow every year, in Croatia there was a noticeable stagnation and decline as shown in the following table.

Table 3: Investing in research and development

\begin{tabular}{|c|c|c|}
\hline Year & Croatia & EU (28) \\
\hline 2004. & 1,03 & 1,76 \\
\hline 2005. & 0,86 & 1,76 \\
\hline 2006. & 0,74 & 1,78 \\
\hline 2007. & 0,79 & 1,78 \\
\hline 2008. & 0,88 & 1,85 \\
\hline 2009. & 0,84 & 1,94 \\
\hline 2010. & 0,74 & 1,93 \\
\hline 2011. & 0,75 & 1,97 \\
\hline 2012. & 0,75 & 2,01 \\
\hline 2013. & 0,82 & 2,03 \\
\hline 2014. & 0,79 & 2,03 \\
\hline
\end{tabular}

Note: Authors according to Eurostat

Table 3 shows the level of investment in research and development in the Republic of Croatia and in the European Union. In addition to the problem of a lack of money, there is also strong competition, the lack of programs to encourage innovation activities and various legal regulations.

\section{COMPETITIVENESS OF CROATIAN ECONOMY}

"The importance of the concept of competitiveness is demonstrated by the fact that it was in the last thirty years one of the most analysed economic terms. Competitiveness has become a natural law of modern economics." (Kitson, Martin, Tyler, 2004:991). Through different periods, many schools of economic theory and its theorists have dealt with the term competitiveness, and each has defined competitiveness in a different way. Generally, competitiveness is a term that everyone tends to achieve, but it is difficult to 
define exactly what it means. European Commission (European Commission, 1999:75) defines competitiveness as the ability to produce goods and services that will meet the challenges of international markets, while maintaining a high and sustainable level of income or, more generally, the ability to create, with the pressures of external competition, and relatively high income and employment levels.

Competitive advantage is what makes enterprises stand out from the rest of the competitors in the market. It is the reason why an enterprise operates. "Competitive advantage can be found under different names such as: unique selling position, recognition, favourable competitive position, discrimination and differentiation" (Porter, 2004:33). The shortcoming of most enterprises is that they do not fully exploit their competitive advantage. Sometimes an enterprise thinks it has a competitive advantage, but is not aware that this is not the case. Another possibility is that an enterprise has a strong competitive advantage, but it is not aware of it and fails to promote it to the customers of their services or goods. Often enterprises, especially small or medium-sized enterprises, do not know how to provide their competitive advantage, which should be the basis for all strategic and operational decisions.

\subsection{Competitiveness of enterprises and competitiveness at national level}

In economic theory, there are two terms pertaining to competitiveness: competitiveness of enterprises and the competitiveness of the country. It is the view of many theorists that competition can only exist at the micro level, while it cannot be discussed at the macro-level (national level). An enterprise is a dynamic system and is subject to influences from the environment, with which it is in constant interaction. An enterprise can affect the environment, and vice versa. When the impact of the environment becomes dominant, the enterprise must monitor the environment in order to identify and reduce threats and negative impacts arising from external environment, and exploit the opportunities provided by the environment. The enterprise's environment represents the entire set of internal and external factors. Knowledge and identification of environmental impacts is essential for the success of the company.

As regards competitiveness of a country, it is often difficult to determine who the target is and what the purpose of its achieving is. There is no definition of competitiveness, as each author defines it in a different way. It is very difficult to explore the competitiveness of a country when the objectives for its determination are not defined. Various traditional elements of economic analysis are used for measuring competitiveness. "Competitiveness is a meaningless word when applied to national economies and therefore its practical usage is not justified." (Reiljan, Hinrikus, Ivanov, 2000:9). Problems that arise in terminology and definition of competitiveness do not justify the elimination of this concept from its use in practice. "At the macro-level national competitiveness or the competitiveness of countries is defined as the ability of the country to achieve economic growth faster than other countries and to increase the well-being, the results are changes of economic structure and effective adjustment to the movement of international trade.” (Bienowski,2006:258) 
"Competitiveness is the ability to co-exist with the other institutions in the conditions of conflict of interests. This type of co-existence (competitiveness) can be characterized by several levels:

- ability to survive - the lowest level of competitiveness, refers to the ability to adapt passively to the competitive environment without significantly changing or developing itself

- ability to develop - the medium level of competitiveness, refers to the ability to respond actively to the changes in competitive environment and thereby improve its own qualities and make its activities more efficient

- Superiority - the highest level of competitiveness, refers to the ability to influence competitive environment through more efficient operation, quicker development or better qualities than competitors." (Reiljan, Hinrikus, Ivanov, 2000:11)

Term competitiveness can be presented in three main groups:

- "Regional competition (local) - choice of suppliers of products or services is limited to the closest environment (often characteristic of market services)

- National Competitiveness - domestic enterprises deliver products or services (characteristic of the internal market which is protected by foreign trade restrictions)

- Global Competitiveness - suppliers of products or services may come from all over the world. The term international competitiveness refers to the fact that in reality the degree of competitiveness is tested only on the global market. " (Garelli 1997:1)

Competitiveness refers to the ability of economic units (enterprises, industries, regions or countries) to compete with its rivals. It represents a rivalry between economic units in the markets or access to human and material resources and technologies. An important feature of competitiveness is its dynamic nature. Sources of competitiveness are not permanent. Eventually, competitors will come up with better ways to perform certain tasks. Economic operators can maintain their competitiveness only through continuous improvement of business processes and products.

"Competitiveness is usually defined at the enterprise level. An enterprise is competitive if it can produce products of better quality and at lower cost than its rivals can. The competitiveness of enterprises includes three dimensions: cost-effectiveness, quality and relative performance. The definition of industrial competitiveness is analogous to the competitiveness of enterprises. However, industrial competitiveness inevitably involves the territorial dimension. Industry is defined as a group of enterprises of similar activity from a particular region or country, and its competitiveness is assessed by groups of producers with similar activities in other regions and countries. At the national level, competitiveness is defined as the ability of competition with other countries." (Nacionalno vijeće za konkurentnost, 55 preporuka za povećanje konkurentnosti Hrvatske, 2004:10) 
Competitiveness at the national level is often burdened by unrealistic limits and possibilities of achieving a competitive advantage. "Some of them are:

- Joining the EU will solve all economic problems;

- We possess highly educated and high-quality workforce;

- We will easily reduce taxes;

- Croatia is attractive to foreign investment, but investors hesitate because of the political situation;

- Economic policy can be led without open discussion about the exchange rate policy;

- The state will open new workplaces;

- The government can solve most problems in one term of office." (Nacionalno vijeće za konkurentnost, 55 preporuka za povećanje konkurentnosti Hrvatske, 2004:9)

According to the guidelines of the National Competitiveness Council, it is necessary to achieve four national strategic objectives:

- "Sustainable GDP growth

- Reduction of unemployment

- Increase in the quality of life

- Increase in social inclusion " (Nacionalno vijeće za konkurentnost, 55 preporuka za povećanje konkurentnosti Hrvatske, 2004:13)

None of these objectives is defined as a value in itself.

In order to achieve competitiveness, a country must develop factors and policies that will create a better market position in relation to other countries. Factors and policies affecting competitiveness are: business environment, economic and technological infrastructure, education and training, innovation and creativity, entrepreneurship and small business development. The development of these factors and policies of creating inter-products is how competitiveness is achieved. Inter-products are productivity, exports, costs and prices, and investment. The result of achieving competitiveness of the national economy is its growth, high rate of employment and increase in the quality of life.

„Competitiveness is the foundation that determines the success or failure of the enterprise. It determines the suitability of activities that contribute performance of enterprise, such as innovation, cohesion organizational culture or good implementation. Competitive strategy is the search for a favourable competitive position within the industry, the basic environment in which competition occurs. Competitive strategy is focused on establishing a profitable and sustainable position despite forces that determine industry competition. “(Porter, 2009:20)

For most enterprises, its competitive advantage is not unique and changes over a long period. Successful enterprises are constantly looking for new competitive advan- 
tages and market research. Such enterprises monitor what their competitors are doing. It is not uncommon to merge with or acquire an enterprise that has a strong competitive advantage, or take over employees who are responsible for creating these benefits. Successful businesses are built on solid foundations, have quality, professional people, good service, tradition, authenticity and so on. However, strengths are not the same as a competitive advantage. Strengths are important to be able to survive in the market, but are not factors of diversity. Finding a competitive advantage is not a one-time job. It is necessary to create a work culture that will constantly maintain a competitive advantage. It is necessary to keep constantly an eye on the competition; awareness of the competition is a kind of competitive advantage.

\subsection{Internal and external competitive forces}

There are two types of competitive advantages, which are divided into external and internal. When it comes to the external competitive advantage, the reputation of the enterprise is the most important, as it is seen by customers. Enterprises often do not bother to find out what is important to the customers. If the enterprise has a competitive advantage that is not presented to customers or is not confirmed, then it is a big disadvantage in business. External competitive advantages include: patented products or specific services which are unavailable to competition, better product quality, quick delivery and so on. The external competitive advantage is clearly visible to the customer. Competitive advantage should be something positive to the customers. It should play an important role in customer's decision where to make a purchase, it must be quantified, satisfy customer expectations and be credible.

"Competitive advantage is not only contained in the products in the services, but also depends of mode in which this is done. This may be the conditions such as: warranties, supplies, financial conditions, packaging, quantity, delivery method, always complete shipment, quick answers to customers questions, unique design, product performance, technical support after purchase, reputation technology expertise, leading sales positions, superior communication, training for use of the product, shipping documents, and easy installation." (Smith, 2007:161)

Internal advantages are not visible to customers, but because of them, the enterprise has a great advantage over its competitors. Advantages develop for years, sometimes for decades. Internal benefits can include huge purchasing power, good organization within the enterprise, good distribution channels, advanced technology and so on. Internal advantages may not affect the daily customers, but are very important for the sustainability of the financial stability, suppliers, bankers, employees and other interested participants. An enterprise has a competitive advantage when it has a different strategy from its competitors. Internal competitive advantage influences customers' decisions, even when customers may not see them. An internal advantage might include purchasing power, substitute products or services, market position, experience, production advantages, distribution advantages, connections with the authorities and so on. Purchasing power comes to play when dealing with large amounts or if an enterprise is a general agent for a particular product. In this case it constitutes a visible advantage over competitors. 
According to Smith (2007) if the enterprise invests in new technologies, if it has access to raw materials and has a lot of storage - then customers should be informed about it, because such enterprise may conduct business faster than the competition. These benefits are production advantages. Distribution advantages entail faster delivery of orders because of the possession of warehouses in good locations or rolling stock that gives priority to the transport of products and materials. Relationship with the authorities relates to situations in business where it comes into contact with regulations and laws, environmental laws, patent rights, but also when it comes to production of products that are dangerous or can be misused, such as certain chemicals, fertilizers or weapons. These are just some of the internal strengths whose purpose is to get the customer feel safe and satisfied.

If an enterprise currently does not have a competitive advantage, then it should be created as soon as possible. Creating a competitive advantage redirects the way of doing business and puts focus on new goals. In some cases, it is enough to invest a little effort in order to create a competitive advantage, while in some cases this requires a lot of resources and time.

\section{CROATIAN POSITION OF COMPETITIVENESS AND INNOVATION}

It is in the interest of every country to be competitive and to have an export oriented industry. The country should strengthen and develop those sections of diplomatic representations dealing with economic diplomacy, at least in the countries of largest trading partners. To be competitive in the demanding EU and other markets is the task of enterprises, as well as all governmental institutions, and should be supported by the entire infrastructure.

\subsection{Competitiveness index}

The following table shows data on competitiveness, ranks and the competitiveness index. Top ten most competitive countries in the world in the year 2016-2017 have been selected, plus the Republic of Croatia. Rankings and indexes are shown for these countries for the years 2015-2016, 2014-2015, 2013-2014, and 2012-2013. 
Table 4: Ranking of competitiveness

\begin{tabular}{|c|c|c|c|c|c|c|c|c|c|c|}
\hline & 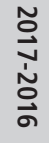 & 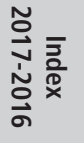 & 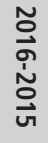 & 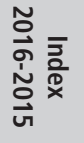 & 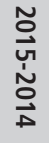 & 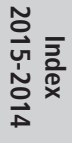 & 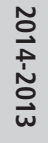 & 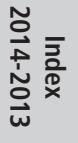 & $\begin{array}{l}\stackrel{\sim}{\circ} \\
\vec{u} \\
\dot{\sim} \\
\stackrel{\sim}{N}\end{array}$ & 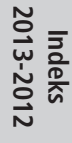 \\
\hline Switzerland & 1 & 5.81 & 1 & 5.76 & 1 & 5.70 & 1 & 5.67 & 1 & 5.72 \\
\hline Singapore & 2 & 5.72 & 2 & 5.68 & 2 & 5.65 & 2 & 5.61 & 2 & 5.67 \\
\hline United States & 3 & 5.70 & 3 & 5.61 & 3 & 5.54 & 5 & 5.48 & 7 & 5.47 \\
\hline Netherlands & 4 & 5.57 & 5 & 5.50 & 8 & 5.45 & 8 & 5.42 & 5 & 5.50 \\
\hline Germany & 5 & 5.57 & 4 & 5.53 & 5 & 5.49 & 4 & 5.51 & 6 & 5.48 \\
\hline Sweden & 6 & 5.53 & 9 & 5.43 & 10 & 5.41 & 6 & 5.48 & 4 & 5.53 \\
\hline United Kingdom & 7 & 5.49 & 10 & 5.43 & 9 & 5.41 & 10 & 5.37 & 8 & 5.45 \\
\hline Japan & 8 & 5.48 & 6 & 5.47 & 6 & 5.47 & 9 & 5.40 & 10 & 5.40 \\
\hline Hong Kong & 9 & 5.48 & 7 & 5.46 & 7 & 5.46 & 7 & 5.47 & 9 & 5.41 \\
\hline Finland & 10 & 5.44 & 8 & 5.45 & 4 & 5.50 & 3 & 5.54 & 3 & 5.55 \\
\hline Croatia & 74 & 4.15 & 77 & 4.07 & 77 & 4.13 & 75 & 4.13 & 81 & 4.04 \\
\hline
\end{tabular}

Source: http://www.weforum.org/

The table shows that the ranking of the most competitive countries in the period from 2016 to 2017 is not the same as in previous periods. Some countries, such as Germany, Switzerland, the Scandinavian countries, the Asian tigers are constantly on top in the observed period. This shows clearly that if a country works on developing its competitiveness it can change its global competitive position. On the other hand, countries that have been constantly on top positions have to make an effort in order to maintain their position. However, the same cannot be said for the competitiveness index of Croatia and the countries within its immediate environment.

Table 5: Ranking of competitiveness of Croatia and countries of the region

\begin{tabular}{|c|c|c|c|c|c|c|c|c|c|c|}
\hline & 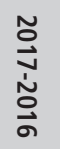 & 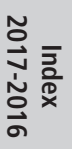 & $\begin{array}{l}\text { O } \\
\text { oे } \\
\text { ஸे } \\
\text { जे }\end{array}$ & 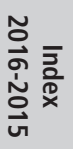 & 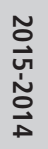 & 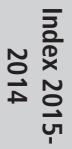 & 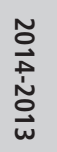 & 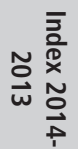 & 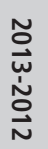 & 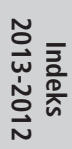 \\
\hline Croatia & 74 & 4.15 & 77 & 4.07 & 77 & 4.13 & 75 & 4.13 & 81 & 4.04 \\
\hline Slovenia & 56 & 4.39 & 59 & 4.28 & 70 & 4.22 & 62 & 4.25 & 39 & 5.05 \\
\hline Bosnia and Herzegovina & 107 & 3.80 & 111 & 3.71 & $n / a$ & $\mathrm{n} / \mathrm{a}$ & 87 & 4.02 & 88 & 3.93 \\
\hline Serbia & 90 & 3.97 & 94 & 3.89 & 94 & 3.90 & 101 & 3.77 & 95 & 3.87 \\
\hline Hungary & 69 & 4.20 & 63 & 4.25 & 60 & 4.28 & 63 & 4.25 & 60 & 4.30 \\
\hline Montenegro & 82 & 4.05 & 70 & 4.20 & 67 & 4.23 & 67 & 4.20 & 72 & 4.14 \\
\hline
\end{tabular}

Source: http://www.weforum.org/

The table shows the competitiveness rankings of Croatia and of the countries in the neighbourhood: Slovenia, Bosnia and Herzegovina, Serbia, Hungary and Monte- 
negro. Almost all mentioned countries now have a much lower rating than in previous years. The worst rank in the observed period is that of Bosnia and Herzegovina and the best is that of Slovenia. Based on its historical heritage, Croatia once operated most and performed most of its international trade on the Eastern European market. Today, the situation is similar, except that it tends to be present also on the market of Western Europe. The following text shows the Croatian competitiveness compared to countries such as the Czech Republic, Poland, Hungary, Slovakia, Romania, Slovenia, and Bulgaria in the period from 2008 to 2017. Graph 1 shows the ratio of Croatian competitiveness and selected countries within its immediate environment.

Graph 1: Croatian competitiveness and competitiveness of selected countries in the period from 2008 to 2017

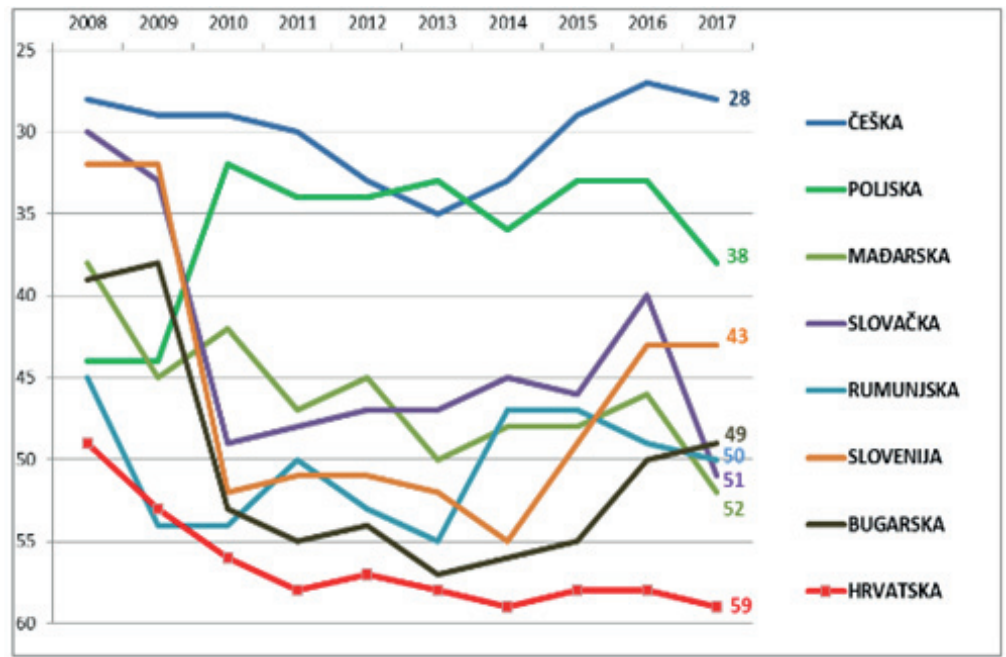

Source: http://konkurentnost.hr/Default.aspx?art=608\&sec $=2$

Graph 1 shows the competitiveness of Croatia and of selected countries within its immediate environment and it is clear that Croatia had a great leap of competitiveness only in 2008. However, in the last 5 years a steady decline has been recorded. In 2017 Croatia has been ranked 59th, while some countries, such as the Czech Republic and Poland, that were in a similar position as Croatia before the transition, are ranked much higher today. However, after 2008, when the economic collapse occurred, some countries such as Poland recorded a further increase. All other countries experienced a decline, some even by 30 ranks in the competitiveness rankings. However, although most countries are experiencing a decline in competitiveness, Croatia remains uncompetitive in relation to those countries. The graph below shows the competitiveness of Croatia, according to IMD in the period 2006-2017. 
Graph 2: Competitiveness of Croatia, according to IMD in the period 2006-2017

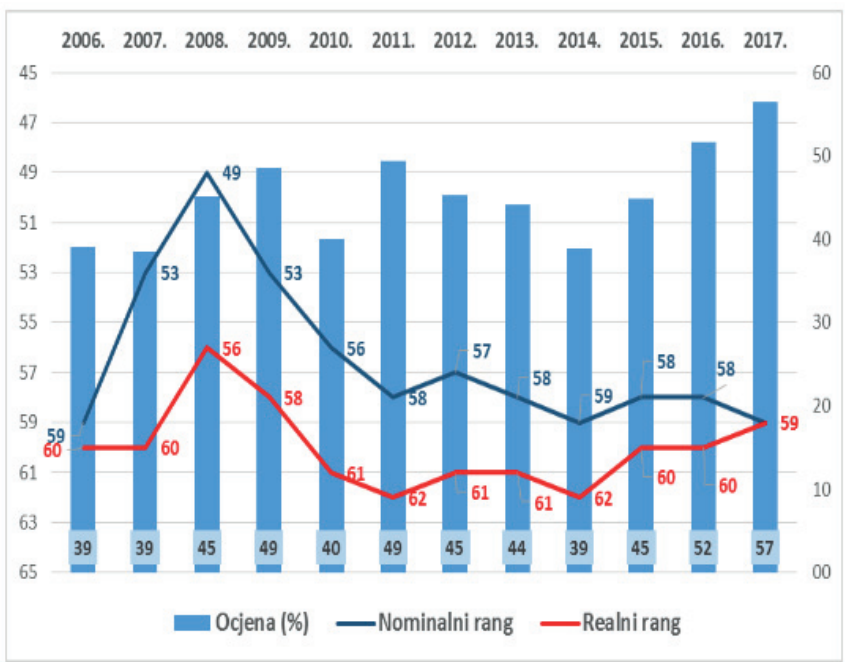

Source: http://konkurentnost.hr/Default.aspx?art=608\&sec=2

The graph shows that in addition to the overall ranking, it is very important to observe the dynamics of the final scoring of competitiveness, and the movement of both nominal and real rank for the period from 2006 to 2017.

\subsection{The main initiators and problems of business competitiveness}

When discussing competitiveness of a country there are numerous elements that constitute shortcomings and weaknesses that have an effect on the development of the Croatian competitiveness. These include costs of agricultural policy, ability to attract talented people, investment incentives, cooperation of employers and employees, employee education, sophistication of customers, protection of investors, cluster development, protection of the interests of minority shareholders, transfer of technology, biased decision-making of government officials, impact on the market, independent system, strengthening of local competition, effectiveness of management boards, transparency of government policies, availability of credit, representation of foreign ownership, willingness to delegate responsibilities, balance of the government budget and others. The following table shows positive indicators and the main problems of competitiveness. 
Table 6: Positive indicators and main problems of business competitiveness in Croatia in 2016

\begin{tabular}{|l|c|l|c|}
\hline Positive indicators & $\mathbf{2 0 1 6}$ & Main problems & Change \\
\hline Institutions & 89 & Health and primary education & 66 \\
\hline Infrastructure & 46 & Development of financial market & 95 \\
\hline Macroeconomic environment & 84 & Technological readiness & 47 \\
\hline Higher education and training & 49 & Innovation & 103 \\
\hline Efficiency of commodity market & 95 & & \\
\hline Efficiency of labour market & 100 & & \\
\hline Size of market & 78 & & \\
\hline Sophistication of the business sector & 80 & & \\
\hline
\end{tabular}

Source: www.konkurentnost.hr

The table shows that most indicators deteriorated in 2017. Positive factors for doing business in the Republic of Croatia in 2016 were: institutions, infrastructure, improvement of the macroeconomic environment, development of higher education and training, efficiency of commodity and labour markets, the size of the market and the sophistication of the business sector. The most problematic factors for doing business in the Republic of Croatia in 2016 included: health and primary education, development of the financial market, technological readiness and innovation.

\subsection{Innovation Index}

Global Innovation Index launched a business school INSEAD in 2007 with an idea to modernize the way of measuring innovation and overcome the traditional approach based on measures such as the number of patents, the number of articles published in scientific journals or investment in research and development. Since 2012, research has joined the Organization and the World Intellectual Property Organization (WIPO).

Table 7: Top 10 countries according to the global innovation index

\begin{tabular}{|c|c|c|c|}
\hline Country & GII 2016. & GII 2015 & GII 2014 \\
\hline Switzerland & 1 & 1 & 1 \\
\hline Sweden & 2 & 3 & 3 \\
\hline United Kingdom & 3 & 2 & 2 \\
\hline United States & 4 & 5 & 6 \\
\hline Finland & 5 & 6 & 4 \\
\hline Singapure & 6 & 7 & 7 \\
\hline Ireland & 7 & 8 & 11 \\
\hline Denmark & 8 & 10 & 8 \\
\hline Netherlands & 9 & 4 & 5 \\
\hline Germany & 10 & 12 & 13 \\
\hline Croatia & 47 & 40 & 42 \\
\hline
\end{tabular}

Note: Authors according to the Global Innovation Index 
The table shows top 10 countries according to the Global Innovation Index for 2014, 2015 and 2016. Switzerland has for many years in a row been ranked first on the Global Innovation Index. In addition to Switzerland, Sweden and the United Kingdom have been ranked second and third, just like in previous years. Taking into account the position of Croatia in relation to the most innovative countries, the chart below shows the trend of the Croatian ranking.

Graph 3: Republic of Croatia according to the Global Innovation Index

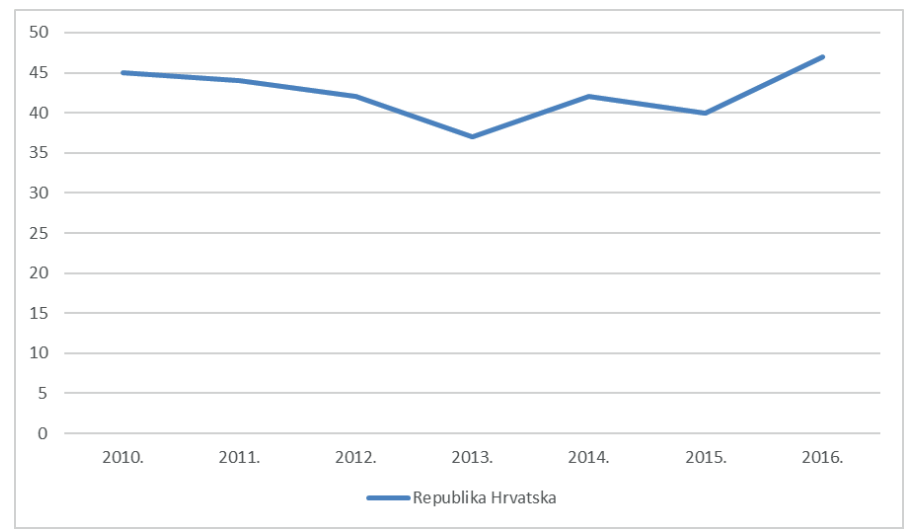

Note: Authors according to the Global Innovation Index

The Graph 3 shows that the innovation position of Croatia is weak when compared to the previous year. Since 2010, with the trend of decline and growth, Croatia had the worst position in 2016 (47th place). With regard to the last tables, it is a fact that the most competitive economies are at the same time the most innovative ones and that those countries are closest to being a knowledge society. Their common denominator is that they all have a strong knowledge-based economy, and invest in the development of innovation. In terms of competitiveness and innovation, the situation in the Republic of Croatia is quite worrisome because it has a decreasing trend in almost all international rankings and reports. The following table shows the position of Croatia and its neighbouring countries according to the results covered by the Global Innovation Index in 2016, 2015 and 2014.

Table 8: Croatian position in relation to neighbouring countries

\begin{tabular}{|l|c|c|c|}
\hline Country & GII 2016 & GII 2015 & GII 2014 \\
\hline Croatia & 47 & 40 & 42 \\
\hline Bosnia and Herzegovina & 87 & 79 & 81 \\
\hline Serbia & 65 & 63 & 67 \\
\hline Slovenia & 32 & 28 & 28 \\
\hline Hungary & 33 & 35 & 35 \\
\hline Montenegro & 51 & 41 & 59 \\
\hline
\end{tabular}

Note: Authors according to the Global Innovation Indeks 
Table 8 shows achieved ranking of Croatia in comparison to neighbouring countries. From the neighbouring countries, Slovenia has achieved the best position, although its position worsened in the last observed year. Right next to Slovenia is Hungary. On the other hand, the worst is Bosnia and Herzegovina, but it does not lag behind Serbia, and Montenegro.

\subsection{The level of Croatian innovation with regard to $\mathrm{EU}$}

One of the most important reports on the assessment of innovation is the Innovation Union Scoreboard initiated by the EU with the aim of comparing innovative activity in the countries and assessing the innovation capacity, the relative strengths and weaknesses of the innovation system in the EU member states. The following figure shows the success of the EU Member States in the field of innovation.

Graph 4: The success of the EU Member States in innovation in 2015

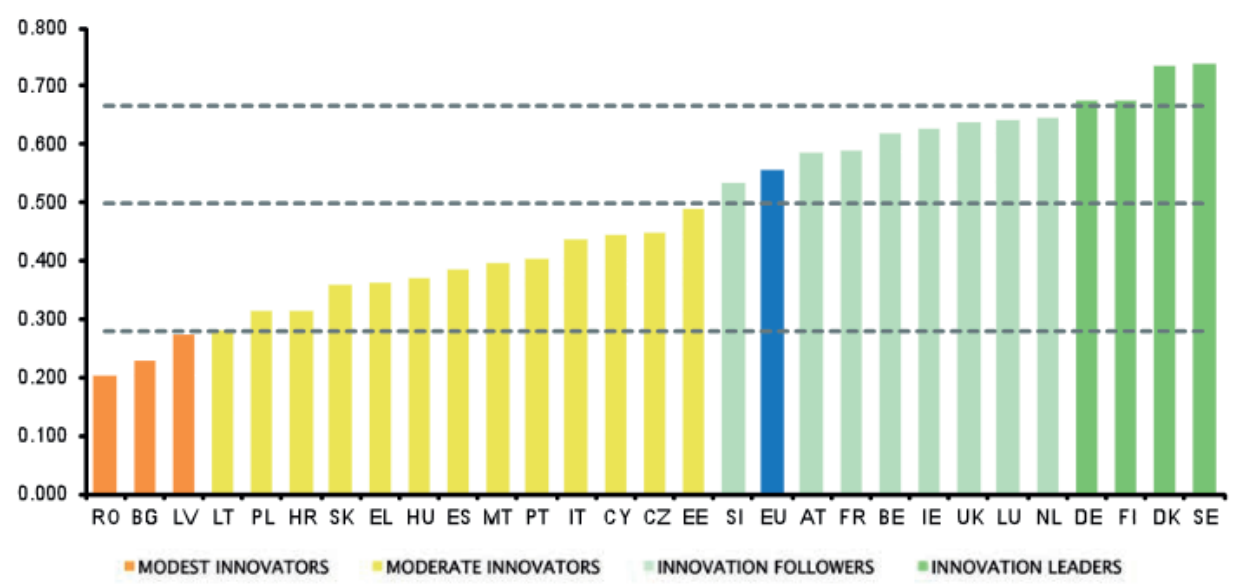

Source: Innovation Union Scoreboard 2015

Graph 4 shows that, based on the average success in the field of innovation, Member States are classified into four main categories of performance. Leaders in the field of innovation (their success in this area is far above the EU average) are Denmark, Finland, Germany and Sweden. Austria, Belgium, France, Ireland, Luxembourg, the Netherlands, Slovenia and the United Kingdom are followers in the field of innovation and their success in that area is over or near the EU average. The success of Croatia, Cyprus, Czech Republic, Estonia, Greece, Hungary, Italy, Lithuania, Malta, Poland, Portugal, Slovakia and Spain is below the EU average and these countries are moderate innovators. Bulgaria, Latvia and Romania are modest innovators, and their success in the field of innovation is far below the EU average. The most innovative EU countries are the most successful in all areas: from funds invested into research and innovation 
results to innovation and economic impacts. The Republic of Croatia is considered a moderate innovator.

\section{CONCLUSION}

The importance of innovation today has far-reaching consequences for the strategy of a country. Global competition has led to a change in the balance of power in the international market relations making innovation a crucial component of competitiveness and an important factor in a particular country. Innovation can contribute to competitiveness in several ways: the existence of a strong correlation between market success and new products, the ability to frequently change products with new improved versions, create a cheaper product or provide cheaper services, create a complex product, etc. Based on the analysed data in this paper, a conclusion can be reached that in Croatia there is a lack of innovation, investment, and therefore the lack of required technological advances. It is necessary to work on the development of valid strategies, both at the level of the enterprise and at the national level, in order to increase the level of competitiveness of Croatia, and to make Croatia not only a regional leader, but an economically high-ranking European country as well.

\section{REFERENCES:}

1. Bienkowski, W (2006). How much are studies of competitiveness worth? Some critical theoretical reflections on the issue, The Second Economic Forum On "New Europe", Lancut, April

2. European Commission (2001). Second Report on Economic and Social Cohesion, http://ec.europa.eu/regional_policy/sources/docoffic/offi cial/reports/contentpdfen.htm [10.02.2015.]

3. Eurostat, http://ec.europa.eu/eurostat/tgm/table.do?tab=table\&init=1\&language= en\&pcode $=$ tsc00001\&plugin $=1_{2}[05.11 .2016$.]

4. Garelli, S. (1997) The Four Fundamental Forces of Competitiveness, Competitiveness Yearbook. http://www.imd.ch/wcy/approach/fondamentals.html 26.09.1997 [22.03.2013.]

5. Green Paper on Innovation 1995. http://aei.pitt.edu/1218/1/innovation_gp_ COM_95_688.pdf, 15.04.2013.

6. Innovation Union Scoreboard, http://www.urenio.org/el/wp-content/uploads/2015/10/1.2.-Innovation-Union-Scoreboard-2015.pdf, [29.11.2016.]

7. Kitson, M., Martin, R., Tyler, P. (2004). Regional Competitiveness: An Elusive yet Key Concept?, Regional Studies, (38), pp. 991-999

8. Nacionalno vijeće za konkurentnost, 2014 http://konkurentnost.hr/Default.aspx?art $=608 \& \sec =2$ [3.07.2017.] 
9. OECD (2005) Oslo Manual - The Measurement of Scientific and Technological Activities: Guidelines for Collecting and Interpreting Innovation Data, 3rd edition, Paris: Organisation for Economic Co-operation and Development

10. Porter, M. E. (2004). Competitive Strategy, Free Press, New York

11. Reiljan, J, Hinrikus, M., Ivanov, A. (2000). Key Issues in Defining and Analysing the Competitiveness of a Country, University of Tartu, Faculty of Economics and Business Administration, Tartu

12. Sirotković, J. (1996). Hrvatsko gospodarstvo- privredna kretanja i ekonomska politika, Hrvatska akademija znanosti i umjetnosti, Golden Marketing, Zagreb, Hrvatska

13. The global innovation index, https://www.globalinnovationindex.org/, [10.11.2016.]

14. Webforum, Global copetitiveness report 2008-2009, http://reports.weforum.org/ global-competitiveness-report-2008-2009/competitiveness-rankings/ [18.02.2014. 


\title{
KONKURENTNOST I INOVACIJSKI IZAZOVI U HRVATSKOJ*
}

\author{
Lena Duspara ${ }^{4}$, Sanja Knežević5 \& Mladen Turuk ${ }^{6}$
}

\begin{abstract}
Sažetak
Konkurentnost je koncept kojeg svi žele postići, ali ga je vrlo teško definirati, a još $i$ teže provesti. Važna značajka konkurentnosti je njezina dinamična priroda, jer izvori konkurentnosti nisu trajni. Konkurentnost ima sve veći značaj za svaku zemlju, koja želi razvijati svoju industriju i gospodarstvo. Za razumijevanje trenutne ekonomske situacije potrebno je poznavati povijesnu pozadinu jer utječe na postojeću situaciju i konkurentnost gospodarstva. Konkurentnost je najčešće definiran ekonomski koncept u posljednjih 30 godina. Interes svake zemlje je da bude konkurentna i da je industrija izvozno orijentirana. Da bi se postigla konkurentnost na zahtjevnom tržištu EU i na globalnom tržištu, zadatak je oboje - i poduzeća i gospodarstva Republike Hrvatske. Svrha rada je povezati medunarodnu konkurentnost s nedostatkom inovativnih aktivnosti u Hrvatskoj. Inovacijski kapaciteti i sofisticiranost proizvodne tehnologije jedan su od glavnih problema poslovne konkurentnosti u Hrvatskoj. Radom se istražuju indikatori konkurentnosti i parametri indeksa konkurentnosti i inovacija koji određuju položaj Republike Hrvatske na regionalnoj i globalnoj razini. Cilj je pokazati utjecaj nacionalne konkurentnosti $i$ standarda inovacija na poduzetništvo u Hrvatskoj.
\end{abstract}

Ključne riječi: konkurentnost, inovacije, problemi, Hrvatska.

JEL klasifikacija: L31, 031

\footnotetext{
Rad je prezentiran na 2. Međunarodnoj konferenciji "Business \& Entrepreneurial Economics-BEE2017” koja je održana na Brijunima od 24. do 26. svibnja 2017. godine (www.bee-conference.com)

4 Dr.sc. Lena Duspara, univ.spec.oec., viši predavač, Veleučilište u Slavonskom Brodu, Slavonski Brod, Hrvatska, E-mail: lena.duspara@vusb.hr

5 Dr.sc. Sanja Knežević, mag.oec., viši predavač, Veleučilište u Slavonskom Brodu, Slavonski Brod, Hrvatska, E-mail: sanja.knezevic@vusb.hr

6 Dr.sc. Mladen Turuk, univ.spec.oec., asistent Ekonomski fakultet - Zagreb, Sveučilište u Zagrebu, Hrvatska, E-mail: mturuk@efzg.hr
} 